\title{
Does post-exercise massage treatment reduce delayed onset muscle soreness? A systematic review
}

\author{
E Ernst
}

\begin{abstract}
Background-Delayed onset muscle soreness (DOMS) is a frequent problem after unaccustomed exercise. No universally accepted treatment exists. Massage therapy is often recommended for this condition but uncertainty exists about its effectiveness.

Aim-To determine whether post-exercise massage alleviates the symptoms of DOMS after a bout of strenuous exercise. Method-Various computerised literature searches were carried out and located seven controlled trials.

Results-Most of the trials were burdened with serious methodological flaws, and their results are far from uniform. However, most suggest that post-exercise massage may alleviate symptoms of DOMS.

Conclusions-Massage therapy may be a promising treatment for DOMS. Definitive studies are warranted.

(Br J Sports Med 1998;32:212-214)
\end{abstract}

Keywords: massage treatment; delayed onset muscle soreness; muscle soreness; exercise

Delayed onset muscular soreness (DOMS) is a predictable painful condition which often occurs after unaccustomed eccentric exercise. It is a benign condition which usually subsides after 3-4 days of relative inactivity. Nevertheless it can lead to considerable suffering and handicaps athletes by temporarily impeding performance and preventing training. Thus an effective treatment has been sought for many years. Among the treatments tried are transcutaneous electrical nerve stimulation, ${ }^{1}$ ultrasound, ${ }^{2}$ and the administration of aspirin and other anti-inflammatory drugs, ${ }^{3}$ steroids, ${ }^{4}$ and vitamin $\mathrm{C}$ and other antioxidants. $^{5}$ To date, none of these approaches has been fully convincing.

Muscle massage could be another candidate for an effective treatment. Recent reviews ${ }^{6-9}$ have pointed out the potential of massage to alleviate DOMS or enhance performance. Inter alia, massage therapy has been shown to increase local blood and lymph flow, decrease oedema production, reduce muscular tone, and enhance mood. ${ }^{6-9}$ None of these (mostly narrative) reviews makes a systematic attempt to summarise the controlled trials on the efficacy of post-exercise massage as a treatment for DOMS. The present systematic review aimed to fill that gap.

\begin{abstract}
Methods
The following databases were searched: Medline, Embase, and the Cochrane Library, each from its institution to July 1997. In addition, the author's own and other experts' files were considered. A study was included if it was conducted against a control group, if it was on human subjects, and if it included outcome measures to quantify DOMS. Foreign language publications were not excluded. Data were extracted in a standardised predefined fashion (table 1). Initially, statistical pooling was considered; this plan had to be abandoned, however, when it became clear that the trials were too heterogeneous for application of meta-analytical techniques.
\end{abstract}

\section{Results}

Seven studies that met the above criteria were located. Table 1 summarises them in chronological order.

Eltze and co-workers ${ }^{10}$ allocated 20 volunteers to receive either three vibrational massages with a mechanical vibrator device or no massages. All volunteers had previously performed eccentric exercises to induce DOMS. There was less decline in isometric strength and more release of creatine kinase with massage. Pain due to DOMS was also numerically less; however, this failed to reach the level of statistical significance. This study was not randomised, leaving it open to selection bias. The sample size was small, rendering a Type II error a realistic possibility.

Wenos and colleagues ${ }^{11}$ induced DOMS in untrained seated adults by asking them to lower a weight of $75 \%$ lean body mass from knee extension to flexion. One side was subsequently massaged by a licensed massage therapist while the other served as a control. Soreness perception was evaluated by questionnaire 24, 48, and 72 hours after exercise. There was no significant difference between the massaged and control sides.

Bale and James ${ }^{12}$ included nine male athletes in their study. After a maximal run, all participants were either rested or massaged manually for 17 minutes, or asked to "warm down" by exercising at a moderate level. DOMS was less in the massaged individuals, who also showed a more rapid decline in lactate levels. This study is relevant for the investigation of DOMS, but the small sample size seriously limits its conclusiveness.

Ellison et $a l^{13}$ randomised 16 volunteers to receive a "retrograde massage", a placebo massage (massage without force), or a rest after a 
Table 1 Summary of the seven trials on the effect of post-excercise massage on delayed onset muscle soreness

\begin{tabular}{|c|c|c|c|c|c|}
\hline First author (year) & $\begin{array}{l}\text { Trial } \\
\text { design }\end{array}$ & Sample & Intervention & Outcome measures & Main results \\
\hline Eltze $(1982)^{10}$ & CCT & 20 healthy volunteers & $\begin{array}{l}\text { Exercise induced soreness of upper } \\
\text { arm and leg followed by daily } \\
\text { interventions for } 3 \text { days of } \\
\text { (A) vibrational massage for } 30 \mathrm{~min} \\
\text { (B) no intervention }\end{array}$ & Pain & Trend for less pain in A $v$ B \\
\hline Wenos $(1990)^{11}$ & $\mathrm{CCT}$ & 9 untrained volunteers & $\begin{array}{l}\text { Exercise induced soreness of both } \\
\text { quadriceps muscles followed by } \\
\text { (A) massage of one leg } \\
\text { (B) other leg no intervention }\end{array}$ & $\begin{array}{l}\text { Soreness perception (by } \\
\text { questionnaire) }\end{array}$ & No difference between sides \\
\hline Bale $(1991)^{12}$ & CCT & 9 male athletes & $\begin{array}{l}\text { Maximal runs followed by } \\
\text { (A) manual massage of legs } \\
\text { (B) "warm down" (run on treadmill } \\
\text { with heart rate at } 120 \text { beats/min) } \\
\text { (C) rest (all for } 17 \mathrm{~min} \text { ) }\end{array}$ & Pain & $\begin{array}{l}\text { Immediately after massage and } \\
12 \text { hours later significantly less } \\
\text { soreness in A } v \text { B or C }\end{array}$ \\
\hline Ellison $(1992)^{13}$ & RCT & 16 healthy volunteers & $\begin{array}{l}\text { Exercise induced soreness followed by } \\
\text { either } \\
\text { (A) retrograde massage } \\
\text { (B) "placebo massage" } \\
\text { (C) rest (all applied only once) }\end{array}$ & $\begin{array}{l}\text { Soreness perception ( } 24 \text { and } \\
48 \text { hours after exercise) }\end{array}$ & $\begin{array}{l}\text { No significant differences } \\
\text { between groups }\end{array}$ \\
\hline $\begin{array}{l}\text { Rodenburg } \\
(1994)^{14}\end{array}$ & RCT & 50 healthy volunteers & $\begin{array}{l}\text { Eccentric exercise with forearm flexors } \\
\text { (A) warm up + stretching before } \\
\text { exercise plus massage after exercise } \\
\text { (B) no such interventions }\end{array}$ & Pain & Less soreness in A $v \mathrm{~B}$ \\
\hline Smith $(1995)^{15}$ & RCT & $\begin{array}{l}19 \text { male untrained } \\
\text { volunteers }\end{array}$ & $\begin{array}{l}\text { Isokinetic eccentric exercise of elbow } \\
\text { flexors and extensors followed } 2 \text { hours } \\
\text { later by } \\
\text { (A) } 30 \text { min manual massage } \\
\text { (B) rest }\end{array}$ & Pain & Less soreness in A $v \mathrm{~B}$ \\
\hline Tiidus $(1995)^{16}$ & RCT & 9 healthy volunteers & $\begin{array}{l}\text { Bout of eccentric quadriceps work } \\
\text { (A) one leg was massaged daily for } 4 \\
\text { days } \\
\text { (B) control leg received no massage }\end{array}$ & Pain & $\begin{array}{l}\text { Pain significantly less after } 48 \\
\text { hours }\end{array}$ \\
\hline
\end{tabular}

bout of maximal isometric knee extensions. Neither muscular torque nor soreness perception were significantly different between these groups. It should be stressed that the massage was applied only once during 24 hours and this may well have been a case of underdosage. The study has been published only as an abstract and therefore several essential details relating to the methodology are unknown.

Rodenburg and colleagues ${ }^{14}$ randomly divided 50 volunteers after maximum eccentric forearm flexions into two groups. Group A carried out warm up and stretching exercises before the test and received 15 minutes of professional massage after the exercise. Group B did not receive either intervention. Group A experienced less DOMS during the 96 hour observation period. The protocol does not allow one to decide whether the pre-exercise preparation or the post-exercise massage had brought about this result.

Smith et $a l^{15}$ assigned 19 untrained men to either 30 minutes of rest or 30 minutes of manual massage after a bout of isokinetic eccentric elbow exercises. This resulted in less DOMS and lower creatine kinase levels in the experimental group. These results would be convincing were it not for the small sample size of the study.

Tiidus and Shoemaker ${ }^{16}$ asked nine volunteers to perform a bout of bilateral eccentric quadriceps work. For each volunteer, one leg only was randomised to receive treatment. Massages were carried out daily for four days. After 48 hours there was, on average, less DOMS in the massaged legs. At other measuring points during the 96 hour follow up, no such difference occurred. Muscle torque values also did not differ between treated and untreated legs. This study was rigorously designed. The therapeutic effects of massage are small. The idea of testing one leg against the other is based on the assumption that the intervention has only local effects, which may not be true.

\section{Discussion}

Most of the above studies are burdened with serious methodological flaws-for example, small sample size. It is therefore difficult to generate a clear picture from the available data. In one $\operatorname{trial}^{10}$ a positive trend emerged. One investigation is inconclusive because two cointerventions were used in parallel. ${ }^{14}$ Two further investigations do not show a significant effect of massage on DOMS, ${ }^{11}{ }^{13}$ and three studies do imply a positive symptomatic effect. ${ }^{12} 1516$ With only one exception, ${ }^{15}$ these studies suffer from using very small sample sizes. The positive trials do not seem to differ from the negative ones in any systematic way.

Some-for example, ${ }^{17}{ }^{18}$ - but not all-for example, ${ }^{19}$-investigations suggest that postexercise massage treatment can increase muscular performance. This effect may be related to the effectiveness (if any) of massage on DOMS.

Several hypotheses on the pathophysiology of DOMS exist. (1) Exercise leads to local accumulation of metabolic waste, which in turn sensitises A-delta and C fibres causing pain. ${ }^{20}$ (2) Exercise causes muscle ischaemia, which results in the production of a pain substance. Pain in turn produces a reflex spasm which, in a vicious cycle, prolongs ischaemia. ${ }^{21}$ (3) Exercise results in intramuscular oedema which activates mechanoreceptors thus causing pain. ${ }^{22}$ (4) Eccentric exercise leads to damage of the connective tissues in the area of the muscle and this damage is responsible for the pain. $^{23}$ (5) Exercise leads to the release of 
inflammatory byproducts, which sensitise nerve fibres thus causing pain. ${ }^{24}$ (6) Exercise leads to destruction within muscle fibres liberating muscle creatine kinase, which is the cause of pain..$^{25}$ Positive effects of massage on pain caused by these mechanisms are conceivable. The hypothesis is that, through its mechanical pressure on muscle tissue, massage treatment leads to enhanced local microcirculatory blood and lymph flow. This, in turn, reduces oedema, ischaemia, or accumulation of substances that directly or indirectly cause pain. Clearly this hypothesis requires further testing in carefully designed experiments.

Thus massage may be a promising intervention for the reduction of DOMS. Its effectiveness should be investigated in a rigorous trial with a sufficiently large sample size. ${ }^{26}$ In such a study, massage should be the only therapeutic intervention. In case massage works via systemic effects, the use of the contralateral side as a control might be ill-advised. Finally multiple post-exercise massages may be more promising than a single intervention.

In conclusion, even though massage has some potential in reducing the symptoms of DOMS, its effectiveness has not been demonstrated convincingly. A definitive study seems to be warranted.

1 Denegar RC, Huff BC. High and low frequency TENS in the treatment of induced musculoskeletal pain: a comparison study. Athletic Training 1988;23:235-7.

2 Hasson S, Mundorf R, Barnes W, et al. Effect of pulsed ultrasound versus placebo on muscle soreness perception and muscular performance. Scand $\mathcal{F}$ Rehabil Med 1990;22: 199-205.

3 Hasson SM, Daniels JC, Divine JG et al. Effect of iboprufen use on muscle soreness, damage and performance: a
preliminary investigation. Med Sci Sports Exerc 1993;1:9prelimi.

4 Jacobs SCJM, Bootsma AL, Willems PWA, et al. Prednisone can protect against exercise-induced muscle damage. $\mathscr{F}$ Neurol 1996;243:410-16.

5 Saxton JM, Donnelly AE, Roper HP. Indices of free-radicalmediated damage following maximum voluntary eccentric and concentrate muscular work Eur F Appl Physiol 1994;68 189-93.
6 Cafarelli E, Flint F. The role of massage in preparation for and recovery from exercise: a review. Sports Med 1992;14: and $1-9$.

7 Callaghan MJ. The role of massage in the management of the athlete: a review. Br F Sports Med 1993;27:28-33.

8 Ernst E, Fialka V. The clinical effectiveness of massage therapy: a critical review. Forschende Komplementärmedizin 1994;1:226-32.

9 Goats GC. Massage: the scientific basis of an ancient art. $\mathrm{Br}$ f Sports Med 1994;28:153-6.

10 Eltze C, Hildebrandt G, Johanson M. Über die Wirksamkeit der Vibrationsmassage beim Muskelkater. Zeitschrift für Physikalische Medizin und Klimatologie 1982;11:366-370.

11 Wenos JZ, Brilla LR, Morrison MJ. Effect of massage on delayed onset muscle soreness. Med Sci Sports Exerc 1990; 22.534.

12 Bale P, James H. Massage, warmdown and rest as recuperative measures after short term intense exercise. Physiotherapy in Sport 1991;13:4-7.

13 Ellison M, Goerhrs C, Hall L, et al. Effect of retrograde massage on muscle soreness and performance [abstract]. Phys Ther 1992;72:100

14 Rodenburg JB, Steenbeek P, Schiereck P, et al. Warm-up, stretching and massage diminish harmful effects of eccentric exercise. Int f Sports Med 1994;15:414-19.

15 Smith LL, Keating MN, Holbert D, et al. The effects of athletic massage on delayed onset muscle soreness, creatine kinase, and neutrophil count: a preliminary report. fOSPT 1994;19:93-9.

16 Tiidus PM, Shoemaker JK. Effleurage massage, muscle blood flow and long-term post-exercise strength recovery. Int 7 Sports Med 1995;16:478-83.

17 Viitasalo JT, Niemelä K, Kaappola R, et al. Warm underwater water-jet massage improves recovery from intense physical exercise. Eur f Appl Physiol 1995;71:431-8.

18 Balke B, Anthony J, Wyatt F. The effects of massage reatment on exercise fatigue. Clin Sports Med 1989;1:189-

19 Cafarelli E, Sim J, Liebesman C, et al. Vibratory massage and short-term recovery from muscular fatigue. Int $\mathcal{F}$ Sports Med 1990;11:474-8.

20 Asmussen E. Observations on experimental muscular soreness. Acta Rheumatologica Scandinavica 1956;2:109-16.

21 De Vries HA. Quantitative electromyographic investigation of the spasm theory of muscular pain. Am f Phys Med 1966;45:119-34.

22 Brendstrup P. Late edema after muscular exercise. Arch Phys Med Rehabil 1962;43:401-5.

23 Komi PV, Burskirk P. Effect of eccentric and concentric muscle conditioning on tension and electrical activity of human muscle. Ergonomics 1972;4:417-34.

24 Smith LL. Acute inflammation: the underlying mechanism in delayed onset muscle soreness? Med Sci Sports Exerc 1991;23:542-51.

25 Mills KR, Newham DJ, Edwards RHT. Muscle pain. In: Melzack R, Wall PD, eds. The textbook of pain. 2nd ed. London: Churchill-Livingstone, 1989

26 Ernst E. Massage, safe and effective. European fournal of Physical and Medical Rehabilitation 1997;7:101.

\section{Commentary}

Massage has been performed on athletes from the ancient right up to the modern Olympiads. Indeed statistics from the Great Britain team in Atlanta in 1996 revealed that massage formed $47 \%$ of all treatments to athletes from all sports. Despite this popular appeal, a consensus about massage from the literature is difficult to obtain because of wide variations in technique, time, area of the body, and outcome measures. ${ }^{1}$ Professor Ernst has looked specifically at the use of massage on athletes with delayed onset muscle soreness (DOMS) and has reviewed papers fulfilling certain criteria. Although he concludes that massage may have some potential for relieving DOMS, he gives some useful words of advice to future researchers in this area. Noting the limitations of the papers he has reviewed, care should be taken to avoid type II errors due to small sample size, to avoid using multiple therapeutic interventions other than massage, and to avoid using the contralateral limb as a control. The last point is particularly pertinent as many researchers may be tempted to do just this to help boost the sample size. As the author points out, the idea that the massage has only a local (unilateral) effect may not be true. This is certainly an observation in recent unpublished work of electrical stimulation of the quadriceps muscle group and in unilateral strength training. ${ }^{2}$

MICHAEL CALLAGHAN

1 Callaghan MJ. The role of massage in the management of the athlete. A review. Br f Sports Med 1993;27:28-33.

2 Pincivero DM, Lephart SM, Karunakara RG. Effects of rest interval on isokinetic strength and functional testing performance after short term high intensity training. Br f Sports Med 1997;31:229-34. 